\title{
POTENSI PRODUKSI BIOFUEL DARI BIOMASSA FITOPLANKTON LAUT SPESIES Chlorella vulgaris, Dunaliella salina DAN Spirulina sp., YANG DITUMBUHKAN DALAM NUTRIEN UNGGUL “MSSIP” TERINDUKSI ION LOGAM Fe, Co, DAN Ni
}

\section{[Biofuel Production Potency of Sea Phytoplankton Biomass, Chlorella vulgaris, Dunaliella salina, and Spirulina sp. Cultured in Fe, Co, Ni lon Metals Induced-Superior MSSIP Nutrient]}

\author{
Syahruddin Kasim ${ }^{1 \star}$, Paulina Taba ${ }^{1}$, Indah Raya ${ }^{1}$, Ruslan $^{2}$ \\ 1) Jurusan Kimia, Fakultas MIPA, Universitas Hasanuddin \\ Jl. Perintis Kemerdekaan Km 10 Tamalanrea,Makassar, 90245 \\ 2) Jurusan Kimia, Fakultas MIPA, Universitas Tadulako \\ Jl. Soekarno Hatta, Kampus Bumi Tadulako Tondo Palu, Telp. 0451- 422611
}

Diterima 30 Maret 2017, Disetujui 19 April 2017

\begin{abstract}
Research about composition of superior nutrients, growth parameters, and best method to maximize production of biomass sea phytoplankton, Chlorella vulgaris, Dunaliella salina, and Spirulina sp. has been performed. The nutrients was named as MSSIP which were consist of following compositions: urea fertilizer, Arschat-M nutrient, Fe:Co:Ni metal ions $(6: 3: 9: 6: 3)$. Methods used were identification and analysis of sea phytoplankton. Determination of optimum growth condition, pure culture, and mass culture were using local raw materials-based engineered nutrients or MSSIP (M. Sjahrul-Syahruddin Kasim-Indah Raya-Paulina Taba). Determination of product density of sea phytoplankton biomass, analyses of carbohydrate content, and lipid biomass were done by using haemocytometer and microscope, Luff Schrol method, and soxhlet method ( $\mathrm{n}$-hexane as solvent), respectively. Morphology of phytoplankton was identified by using a digital camera microscope, SZ60/sZ60-61. Furthermore, to understand the effect of metal ions, Fe, Co, and Ni added into MSSIP nutrient, identification of nutrient before and after culturing process were done using XRF-ThermoFisher. The results showed that Chlorella vulgaris, Dunaliella salina, and Spirulina sp. were suitable as raw materials to produce biofuel. Those three phytoplankton contained $0,3095 \mathrm{~g} / \mathrm{L}, 0,3782 \mathrm{~g} / \mathrm{L}$, and $0,3325 \mathrm{~g} / \mathrm{L}$ biomass, $32,49 \% \mathrm{w} / \mathrm{w}, 31,58 \% \mathrm{w} / \mathrm{w}$, and $29,81 \% \mathrm{w} / \mathrm{w}$ carbohydrates; and $25,95 \% \mathrm{w} / \mathrm{w}$, $26,82 \% \mathrm{w} / \mathrm{w}$ and $24,53 \% \mathrm{w} / \mathrm{w}$ lipid, respectively. Best optimum condition of culture were salinity of $30-$ $35 \%$, temperature of $20-30{ }^{\circ} \mathrm{C}, \mathrm{pH}$ of $8-9$, initial density of $2.5 \times 104 \mathrm{cell} / \mathrm{mL}$, light exposure of 40 watt, and continuously aerated with $\mathrm{CO} 2$. Based on our study, sea phytoplankton, Chlorella vulgaris, Dunaliella salina, and Spirulina sp. have a high potency as source of bioethanol and biodiesel.
\end{abstract}

Keywords: mass culture, superior nutrient MSSIP, sea phytoplankton biomass, Fe, Co, Ni metal ions

\begin{abstract}
ABSTRAK
Telah dilakukan penelitian tentang komposisi nutrien unggul, parameter pertumbuhan dan metode terbaik untuk memaksimalkan produksi biomassa fitoplankton laut uji spesies Chlorella vulgaris, Dunaliella salina, dan Spirulina sp. Nutrien tersebut diberikan nama nutrien MSSIP dengan komposisi sebagai berikut yaitu: pupuk urea : nutrien Arschat-M : ion logam Fe: $\mathrm{Co}: \mathrm{Ni}=6: 3: 9: 6: 3$. Metode yang digunakan: Identifikasi dan analisis fitoplankton laut. Penentuan kondisi pertumbuhan optimum, kultur murni dan kultur massal menggunakan nutrien hasil rekayasa berbasis bahan baku lokal yang disingkat "MSSIP" (M. Sjahrul-Syahruddin Kasim-Indah Raya-Paulina Taba). Penentuan kepadatan produk biomassa fitoplankton laut yang dihasilkan menggunakan haemocytometer dan mikroskop Nicon, analisis kandungan karbohidrat dengan metode Luff Schrol dan lemak biomassa dengan pelarut n-heksana metode Soxhlet (SNI 2453-90), selanjutnyaidentifikasi dilakukan dengan Mikroskop Digital Camera SZ60/SZ60-61terhadap fitoplankton untuk melihat penampang morfologisnya, dan
\end{abstract}


terakhir identifikasi dengan XRF-Thermo-Fisher terhadap nutrien sebelum dan setelah kultur untuk melihat pengaruh ion logam $\mathrm{Fe}$, Co dan Ni yang ditambahkan dalam nutrien MSSIP yang digunakan. Hasil penelitian,fitoplankton laut spesies Chlorella vulgaris, Dunaliella salinadan Spirulina sp., sangat baik digunakan sebagai bahan baku untuk produksi biofuel oleh karena memiliki kandungan biomassa: 0,3095 g/L, 0,3782 g/L dan 0,3325 g/L, karbohidrat: 32,49\%b/b, 31,58\%b/b dan 29,81\%b/b dan lemak: $25,95 \% \mathrm{~b} / \mathrm{b}, 26,82 \% \mathrm{~b} / \mathrm{b}$ dan $24,53 \% \mathrm{~b} / \mathrm{b}$. Berdasarkan kandungan tersebut, maka Chlorella vulgaris, Dunaliella salina, dan Spirulina sp. berpotensi sebagai penghasil biofuel jenis bioetanol dan biodiesel. Kondisi optimum kultur yang terbaik adalah: salinitas $30-35 \%$, suhu $20-30^{\circ} \mathrm{C}$, pH $8-$ 9, kepadatan awal $2,5 \times 10^{4} \mathrm{sel} / \mathrm{mL}$, penyinaran dengan lampu neon 40 watt dan laju aerasi $\mathrm{CO}_{2}$ kontinyu.

Kata kunci: Kultur massal, nutrien unggul MSSIP, biomassa fitoplankton laut,ion logam $\mathrm{Fe}, \mathrm{Co}$, dan Ni. 


\section{LATAR BELAKANG}

Fitoplankton laut saat ini menjadi fenomena yang penting untuk dikaji lebih mendalam. Hal ini oleh karena fitoplankton memiliki kemampuan untuk mensintetis sendiri bahan organiknya melalui proses fotosintesis, menyebabkan fitoplankton menjadi sumber utama pada rantai makanan di ekosistem air laut dan air tawar (Bu-Olayanet al., 2011). Selain itu, fitoplankton laut merupakan salah satu alternatif sebagai sumber bahan baku untuk pembuatan Bahan Bakar Nabati dalam bentuk biofuel karena memiliki kandungan karbohidrat dan lemak yang cukup tinggi (Hedges et al., 2002; Kasim dkk., 2012).

Wilayah Indonesia memliki dua pertiga daerah berupa lautan dan mempunyai garis pantai terpanjang di dunia yaitu $\pm 80.791,42 \mathrm{Km}$, memiliki kandungan fitoplankton yang melimpah, sekitar 35.000 spesies telah diidentifikasi. Kandungan Karbohidrat Fitoplankton laut Chlorella sp.18,4 - 54,5 \% dan Chlorella vulgaris 10,3 - $44 \%$ (Guerrero, 2010).Dunaliella salina 32\% (Becker, E.W., 1994). Chlorella sp. 18,4 - 54,5\% dan Tetraselmis suecia $11-47 \%$ (Ragauskas, 2006). Chlorella sp., Dunaliella sp., Tetraselmis chuii, Chaetoceros calcitrans, Chaetoceros gracilis, Isocrysis aff galbana, memiliki kandungan kardohidrat sekitar 29-31\% (Kasim dkk, 2012).

Kandungan lemak fitoplankton Chlorella vulgaris, Spirulina platensis, euglena gracilis, Nitzschia palea sekitar 9 - 20 \% (Hadiyanto dkk, 2010). Spirulina 11,2 - 20,8 \%, Nannochloropsis 20,8 $35,5 \%$ dan Botrycoccus 70\% (Chisti, , 2007). Chaetoceros calcitrans 39,8\% (Rodolfi et al., 2008). Tetraselmis sp. 14,7 $\%$, Isochrysis sp. $27,4 \%$ dan sceletonema costatum 21\%(Khanet al., 2009). Berdasarkan informasi ini, sehinggafitoplanktonpotensil untuk diolah menjadi bioetanol dan biodisel, walaupun kandungan ini masih dapat berbeda apabila kondisi lingkungan tumbuhnya juga berbeda.

Potensi fitoplankton sebagai sumber biofuel sangat menjanjikan dan Indonesia melalui Pemerintah sangat serius untuk itu. Tahun 2025 berdasarkan cetak biru pengelolaan energi Nasional di Kementerian Energi dan Sumber Daya Mineral Republik Indonesia, biofuel ditargetkan mengganti $5 \%$ konsumsi bahan bakar konvensional. Selain itu, pada jangka panjang akan terjadi kompetisi hebat dalam pemanfaatan lahan untuk produksi biofuel dengan pangan dan pakan sehingga fitoplankton sangat potensil (Arifin, 2010).

Memanfaatkan fitoplankton untuk bahan baku bioetanol dan biodisel sangat ramah lingkungan, karena tidak menyebabkan polusi dan relatif mudah pengerjaannya serta memiliki produktifitas sebagai sumber nabati mencapai 200 kali dibanding sumber nabati yang lain (Chisti, 2007). Keuntungan lain dari fitoplankton, yaitu memiliki kemampuan menyerap gas 
karbondioksida

$\left(\mathrm{CO}_{2}\right)$

dan mengkonversikannya menjadi oksigen. Sebanyak 90\% dari bobot kering fitoplankton menyerap $\mathrm{CO}_{2}$ sehingga mampu mengurangi gas tersebutsampai 1.000 ton/ha/tahun (Wu et al., 2010).

Pertumbuhan fitoplankton memiliki siklus hidup yang pendek sehingga memiliki respon yang cepat terhadap perubahan lingkungan dan biomassanya dapat menjadi sangat banyak dalam waktu yang singkat apabila distimulasi dengan suatu komposisi nutrien yang dibutuhkan (Nontji, 2008).Parameter yang berpengaruh terhadap akumulasi jumlah biomassa fitoplankton dalam kultur adalah komposisi nutrien, tekanan osmosis, suhu, $\mathrm{pH}$, pencahayaan, laju alir gas $\mathrm{CO}_{2}$ dan salinitas (Sharmaet al., 2012).

Terdapat delapan komponen besar faktor media yang mempengaruhi produktivitas sel biomassa spesies fitoplankton, antara lain suhu, intensitas cahaya, ukuran dan jumlah inokulum, muatan padatan terlarut, salinitas, ketersediaan makronutrien dan mikronutrien $(\mathrm{C}, \mathrm{N}, \mathrm{P}, \mathrm{K}, \mathrm{S}, \mathrm{Mg}, \mathrm{Na}, \mathrm{Cl}$, $\mathrm{Ca}$, dan $\mathrm{Fe}, \mathrm{Zn}, \mathrm{Cu}, \mathrm{Ni}, \mathrm{Co}$, dan $\mathrm{W}$ ) (Sanchez et al., 2008). Logam-logam ini dalam nutrien pembiakan, menunjang pertumbuhan fitoplankton sebab berperan menstimulasi terjadinya peningkatan jumlah biomassa sesuai dengan jumlah yang dibutuhkan (Sanusi, , 2006). Selain itu pertumbuhan sel fitoplankton dipengaruhi oleh faktor lingkungan seperti komposisi nutrien dalam media dan temperatur $\left(16-38{ }^{\circ} \mathrm{C}\right.$ ) (Sanchez et al., 2008; Goksan et al.,, 2007).

Berdasarkan hasil orientasi itulah, dicoba melakukan kajian lebih mendalam mengenai beberapa spesies fitoplankton laut.Terutama melihat pola interaksinyadalam nutrien MSSIP yang diinduksi denganion logam $\mathrm{Fe}$, Co dan $\mathrm{Ni}$. Ketiga logam tersebut termasuk dalam satu golongan VIIIB, kana tetapi memiliki pola interaksi dan fungsi yang berbeda satu sama lain (Sjahrul, 2010).

Logam besi (Fe) berperan aktif dalam reaksi enzimatik proses fotosintesis dan dalam bentuk firridoksin, juga ditemukan bahwa Fe bersama Nikel (Ni) berperan aktif dalam proses asimilasi dengan senyawa lain (Cermeno et al., 2010). Logam kobalt (Co) merupakan komponen utama vitamin B12 dan berperan penting dalam proses metabolisme dan pertumbuhan sel fitoplankton (Colemanet al., 2008). Pada Jaringan tubuh fitoplankton, kelarutan kedua logam berdasarkan reaktifitasnya adalah Fe>Co (Sanusi, 2006).

Berdasarkan latar belakang masalah ini terdorong untuk dilakukan penelitian tentangpotensi produksi biofuel dari spesies fitoplankton lautChlorella vulgaris, Dunaliella salina danSpirulina sp., yang ditumbuhkan dalam nutrien unggul MSSIPterinduksi ion logam $\mathrm{Fe}$, Co dan $\mathrm{Ni}$. Penggunaan tiga jenis ion logam ini diharapkan akan diperoleh pemetaan yang lebih detail tentang interaksi logam tersebut terhadap spesies fitoplankton laut 
uji yang dipakai dalam penelitian ini oleh karena ketiga ion logam tersebut berada pada golongan yang sama dalam tabel periodik unsur.

\section{METODE PENELITIAN}

Penelitian ini dirancang beberapa tahapan mulai penentuan lokasi pengambilan sampel spesies fitoplankton laut, kemudian kultur untuk mendapatkan biomassa, kandungan karbohidrat dan lemak yang tertinggi. Prosedur penelitian terdiri atas beberapa tahapan, yaitu:

\section{Uji Parameter Fisika-Kimia Perairan}

Untuk mengetahui kondisi pertumbuhan fitoplankton yang akan digunakan, dilakukan pengukuran beberapa parameter fisika-kimia sampel air dari perairan laut yaitu: Suhu, salinitas, dan $\mathrm{pH}$ secara In situ. Data Parameter fisika-kimia di lapangan tempat pengambilan sampel air laut, dijadikan dasar untuk kultur fitoplankton laut.

\section{Identifikasi Spesies Fitoplankton Laut Uji dan Kultur Murni}

Dalam penelitian ini, sampel murni spesies fitoplankton uji yang didapatkan dari berbagai tempat, ditanam pada media agar untuk diseleksi dan diamati dengan mikroskop dan SEM untuk diambil gambarnya. Selanjutnya penyiapan media kultur yang akan digunakan, merupakan hasil modifikasi beberapa komponen media kultur menggunakan air laut buatan, dengan membuat variasi komposisi ion logam $\mathrm{Fe}$, Co dan $\mathrm{Ni}$, selanjutnya medium yang dihasilkan dinamakan medium "MSSIP". Konsentrasi masing-masing lon logam yang digunakan adalah, untuk Fe : 1, 2, dan 3 ppm, Co : 0,1; 0,2; dan 0,3 ppm, dan $\mathrm{Ni}: 0,01$ ppm. Nutrien yang dihasilkan sebelum dan sesudah kultur dianalisis dengan XRF dan spektroskopi IR, hasilnya dibandingkan dengan standar dan diukur pada kondisi yang sama.

Bibit sel fitoplankton ini kemudian ditanam ke dalam medium MSSIPpada volume $50 \mathrm{~mL}, 250 \mathrm{~mL}$, dan $500 \mathrm{~mL}$ lalu dalam botol kultur $1000 \mathrm{~mL}$. Selanjutnya dilakukan kultur berdasarkan parameter fisika-kimia yang ditemukan secara insitu dengan mengatur laju alir gas $\mathrm{CO}_{2}$ untuk memperbanyak bibit selain disimpan untuk kultur induk fitoplankton. Cara ini dilakukan berulang pada semua sampel spesies fitoplankton laut yang akan digunakan dengan membuat perlakuan dan kondisi yang sama.

\section{Kultur Spesies Fitoplankton Laut Uji pada Tahap Germinasi}

Kultur fitoplankton pada tahap germinasi, sama dengan kultur murni namun volume kultur dibuat lebih banyak yaitu dalam wadah 3 liter.

Untuk kedua botol kultur 3 liter, setiap hari selama sepuluh hari kultur, diamati dengan alat Haemositometer melalui mikroskop. Pada kultur ini akan diamati laju pertumbuhan spesifiknya dengan menggunakan rumus:

$$
\mu=\frac{\ln \mathrm{N}_{\mathrm{t}}-\ln \mathrm{N}_{0}}{\mathrm{t}}
$$


Keterangan:

$\mathrm{t}=$ Waktu (jam).

$\mathrm{N}_{\mathrm{t}}=$ Kepadatan populasi sel pada saat $\mathrm{t}$ (sel/mL)

$\mathrm{N}_{\mathrm{o}}=$ Kepadatan populasi sel pada saat awal $(\mathrm{sel} / \mathrm{mL})$

$\mu=$ Tetapan laju pertumbuhan spesifik (jam1)

\section{Kultur Massal Spesies Fitoplankton Laut Uji}

Berdasarkan pada parameter fisikakimia kondisipertumbuhanfitoplankton di lapangan yang diukur secara insitu, spesies fitoplankton laut terpilih kemudian dikultur secara massal dalam aquarium bervolume 60 liter, dengan mengatur laju alir gas $\mathrm{CO}_{2}$. Setelah kepadatan fitoplankton optimal, selanjutnya 1 liter dari kultur massal diambil, disaring dan dikeringkan untuk ditentukan berat biomassanya dengan menggunakan metode gravimetri melalui penimbangan dengan kertas saring yang sesuai. Selanjutnya dilakukan pemanenan dengan cara cahaya dan aerasi dihentikan sekitar 3 hari agar terjadi pemisahan antara air dan fitoplankton karena terjadi pengendapan.

\section{Analisis Karbohidrat, Lemak dan biomassa Fitoplankton Laut}

Analisis biomassa dilakukan secara gravimetri, analisis kandungan karbohidrat dalam biomassa fitoplankton laut dilakukan dengan menggunakan metode penentuan gula reduksi dengan cara Luff Schoorl.Komposisi lemak yang terdapat dalam biomassa spesies fitoplankton laut uji terpilih dilakukan dengan pelarut $\mathrm{n}$ heksana metode Soxhlet (SNI 2453-90).

\section{HASIL DAN PEMBAHASAN}

\section{Parameter Fisika-Kimia Perairan}

Parameter fisika-kimia perairan untuk pertumbuhan spesies fitoplankton laut yang ditemukan, hasilnya disajikan pada Tabel 1.

Tabel 1. Data Parameter Fisika-Kimia Pertumbuhan Fitoplankton Laut.

\begin{tabular}{lcccccc}
\hline $\begin{array}{c}\text { Jenis } \\
\text { Fitoplankton }\end{array}$ & \begin{tabular}{c} 
Parameter Fisika-Kimia Kultur Pertumbuhan Fitoplankton Laut \\
\cline { 2 - 7 } \\
$(\mathbf{\%})$
\end{tabular} & $\mathbf{p H}$ & Suhu( $\left.{ }^{\circ} \mathbf{C}\right)$ & $\begin{array}{c}\text { Lampu } \\
\text { Penerangan }\end{array}$ & $\begin{array}{c}\text { Aerasi } \\
\text { (Kontinyu) }\end{array}$ & $\begin{array}{c}\text { Kepadatan } \\
\text { awal sel/mL }\end{array}$ \\
\hline Dunaliella salina & 35 & 8,7 & $20-30$ & Neon 40 watt & Udara blower & 25.000 \\
Chlorella vulgaris & 30 & 8,5 & $20-30$ & Sda & Sda & 25.000 \\
Spirulina sp. & 30 & 8,6 & $20-30$ & Sda & Sda & 25.000 \\
\hline
\end{tabular}

Berdasarkan Tabel 1, variabel yang dibuat tetap yaitu lampu neon 40 watt untuk penyinaran, menggunakan blower sebagai sumber aerasi $\mathrm{CO}_{2}$. Variabel yang bervariasi adalah: Kepadatan awal $25.000 \mathrm{sel} / \mathrm{mL}, \mathrm{pH}$ yang digunakan berada pada kisaran $8-9$, salinitas adalah $30 \%_{0^{-}}$ $35 \%$ o dan suhu berada pada rentang sekitar $20-30{ }^{\circ} \mathrm{C}$. Berdasarkan kondisi sifat fisika-kimia yang dihasilkan ini menunjukkan bahwa fitoplankton laut sangat selektif dalam proses pertumbuhannya oleh karena membutuhkan penyinaran dan aerasi yang cukup dan secara terus menerus, $\mathrm{pH}$ pertumbuhan yang baik cenderung basa serta kepadatan awal, suhu dan salinitas 
yang sesuai, agar dapat membentuk biomassa dengan cepat dan lebih banyak.

\section{Hasil Identifikasi Spesies Fitoplankton Laut Uji dan Nutrien Kultur}

Sampel spesies fitoplankton laut uji hasil seleksi, selanjutnya dianalisis dengan foto mikroskop digital kamera SZ60/SZ60-61, data ini dibandingkan dengan foto fitoplankton laut standar, hasil foto mikroskop yang diperoleh dan disajikan pada Tabel 2.
Berdasarkan data hasil foto mikroskop fitoplankton laut spesies yang diuji dalam penelitian ini, memiliki kesesuaian yang signifikan sebagaimana disajikan pada Tabel 2. Olehnya itu dilakukan kultur lebih lanjut untuk melihat potensi kandungan karbohidrat dan lemak dalam biomassa yang dihasilkan yang menjadi dasar untuk diolah lebih lanjut menjadi biofuel jenis bioetanol dan biodisel.

Tabel 2.Hasil Foto Mikroskop Digital Kamera Spesies Fitoplankton Laut.

\begin{tabular}{|c|c|c|c|}
\hline No. & Fitoplankton & Foto 1 (Hasil Kultur) & Foto 2 (Standar) \\
\hline 1 & Dunaliella salina & & \\
\hline 2 & Chlorella vulgaris & & \\
\hline 3 & Spirulina sp. & & \\
\hline
\end{tabular}

Peremajaan kultur murni fitoplankton laut uji dilakukan berdasarkan parameter fisika-kimia yang ditemukan dengan nutrien yang terbaik untuk memperbanyak bibit dan memaksimalkan laju kepadatan pertumbuhan sel fitoplankton laut tersebut, selain disimpan untuk kultur induk fitoplankton. Cara ini dilakukan pada semua sampel fitoplankton laut yang digunakan dengan membuat perlakuan yang sama, serta didukung oleh data kepadatan jenis pertumbuhannya.

\section{Kepadatan Jenis Sel Fitoplankton Laut Pada Kultur Murni}

Hasil penentuan kepadatan jenis sel spesies fitoplankton laut uji pada kultur murni, diukur dengan Haemocytometer dan dianalisis pada mikroskop Nikon, diperoleh informasi tentang potensi kepadatan sel fitoplankton laut yang bersangkutan sebagai sumber biomassa yang potensial kandungan karbohidrat dan lemaknya.

Hasil pengukuran kepadatan jenis pertumbuhan sel spesies fitoplankton laut yang dianalisis, diperlihatkan pada 
Gambar 1 - 3 dan data kepadatan pertumbuhan fitoplankton laut disajikan pada Tabel $3-5$. Untuk fitoplankton laut spesies $D$. salina, data kepadatan jenis pertumbuhan sel dalam nutrien MSSIP yang digunakan, disajikan pada Tabel 3 dan dalam bentuk grafik disajikan pada Gambar 1.

Tabel 3.Kepadatan Jenis Fitoplankton Laut Spesies $D$. salina.

\begin{tabular}{ccccccccccccc}
\hline Nutrien dan & \multicolumn{1}{c}{ Kepadatan Pertumbuhan Fitoplankton $\mathbf{( x ~ 1 0} \mathbf{4}$ sel/mL) } \\
\cline { 2 - 14 } Sampel & $\mathbf{1}$ & $\mathbf{2}$ & $\mathbf{3}$ & $\mathbf{4}$ & $\mathbf{5}$ & $\mathbf{6}$ & $\mathbf{7}$ & $\mathbf{8}$ & $\mathbf{9}$ & $\mathbf{1 0}$ & $\mathbf{1 1}$ & $\mathbf{1 2}$ \\
\hline A dan A & 2,5 & 13 & 35 & 105 & 398 & 825 & 953 & 1106 & 1245 & $\mathbf{1 3 2 8}$ & 1201 & 1103 \\
B dan KA & 2,5 & 14 & 30 & 172 & 218 & 345 & 413 & 518 & 635 & $\mathbf{8 2 7}$ & 720 & 562 \\
C dan A1 & 2,5 & 102 & 435 & 852 & 1117 & 1443 & 1563 & $\mathbf{1 7 1 8}$ & 1525 & 1183 & 914 & 825 \\
D dan A2 & 2,5 & 80 & 103 & 252 & 317 & 415 & 593 & 688 & 835 & 980 & $\mathbf{9 9 4}$ & 921 \\
E dan A3 & 2,5 & 11 & 29 & 35 & 44 & 58 & 88 & 120 & $\mathbf{1 3 9}$ & 115 & 85 & 77 \\
F dan A4 & 2,5 & 173 & 535 & 932 & 1125 & 1343 & 1518 & $\mathbf{1 6 9 0}$ & 1425 & 1302 & 1034 & 821 \\
F1 dan A4-1 & 10 & 231 & 714 & 1213 & 1545 & $\mathbf{2 1 9 2}$ & 1321 & 917 & 775 & 701 & 854 & 816 \\
F2 dan A4-2 & 10 & 214 & 595 & 931 & 1128 & 1305 & 1411 & 1698 & $\mathbf{1 8 9 2}$ & 1620 & 1374 & 1052 \\
G dan A5 & 2,5 & 123 & 335 & 652 & 917 & 1143 & 1213 & $\mathbf{1 2 2 1}$ & 1095 & 1003 & 973 & 926 \\
H dan A6 & 10 & 114 & 240 & 426 & 675 & 917 & 1045 & 1285 & 1609 & $\mathbf{2 2 4 3}$ & 1821 & 1335 \\
J dan A9 & 10 & 72 & 253 & 485 & $\mathbf{8 1 4}$ & 619 & 501 & 405 & 325 & 230 & 136 & 109 \\
\hline
\end{tabular}

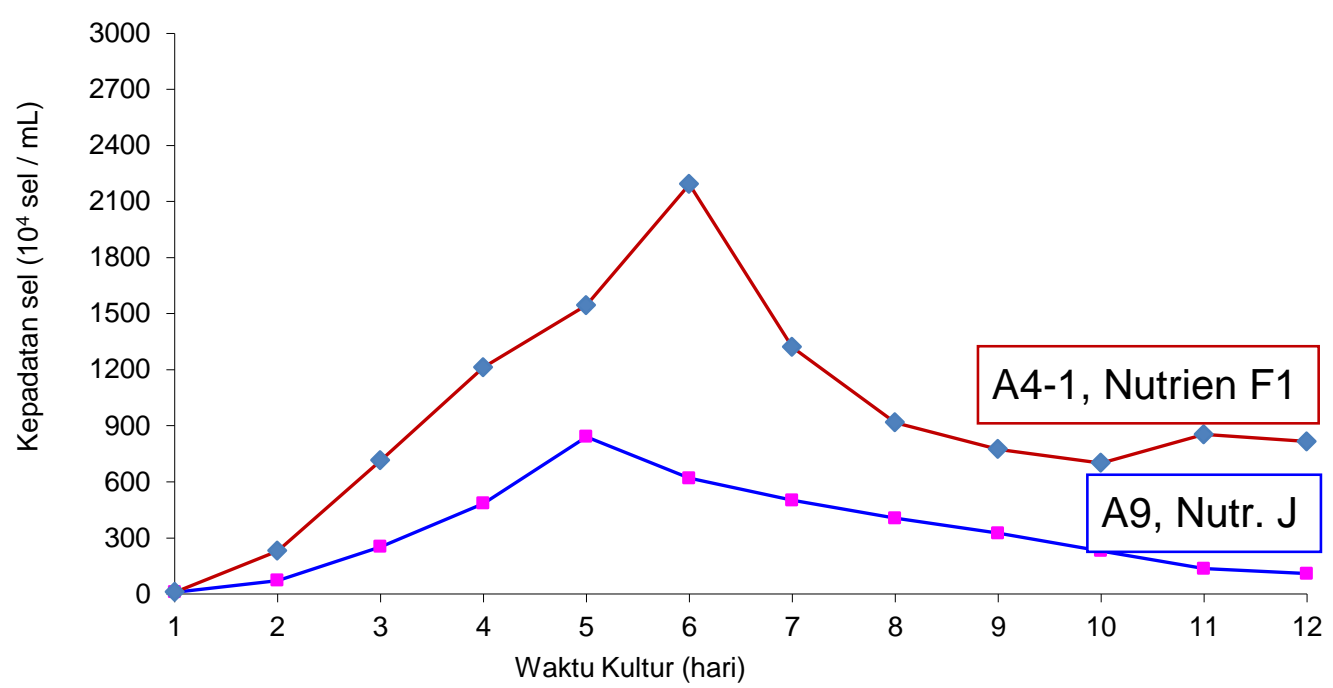

Gambar 1. Grafik Pertumbuhan Sel Spesies D. salina

Berdasarkan data pada Tabel 3 dan Gambar 1, laju tercepat kepadatan pertumbuhan sel fitoplankton laut spesies $D$. salina, diperoleh dalam nutrien $\mathrm{J}$ dengan komposisi nutrien yaitu, Urea : ZA : Arschat-M : Fe: $\mathrm{Co}: \mathrm{Ni}=9: 3: 3: 9: 6$ : 3 , yang dicapai pada awal hari ke 5 kultur yaitu $814 \times 10^{4} \mathrm{sel} / \mathrm{mL}$. Sementara laju pertumbuhan sel dengan jumlah terbanyak terjadi dalam nutrien $\mathrm{F} 1$ dengan komposisi nutrien yaitu, Urea : Arschat-M : Fe: $\mathrm{Co}: \mathrm{Ni}=6: 3: 9: 6: 3$, yang dicapai pada awal hari ke 6 kultur, yaitu $2192 \mathrm{x}$ $10^{4} \mathrm{sel} / \mathrm{mL}$.

Informasi ini menunjukkan bahwa komponen pupuk urea dan pupuk ZA berpengaruh efektif mempercepat laju kepadatan pertumbuhan sel fitoplankton 
laut spesies $D$. salina, akan tetapi tidak secara linier mempengaruhi laju akumulasi pertumbuhan sel dengan jumlah terbanyak. Artinya komponen nutrien ion logam $\mathrm{Fe}$, Co dan $\mathrm{Ni}$ yang digunakan efektif mempercepat laju kepadatan pertumbuhan sel spesies fitoplankton laut spesies $D$. salina dalam nutrien $\mathrm{J}$ dengan keterlibatan komponen pupuk urea dan pupuk ZA. Sedangkan komponen nutrien ion logam $\mathrm{Fe}$, Co dan
$\mathrm{Ni}$ efektif meningkatkan laju akumulasi dengan jumlah terbanyak sel fitoplankton laut spesies $\quad D$. salina dalam nutrien F1 dengan keterlibatan komponen nutrien Arschat-M.

Untuk fitoplankton laut spesies $C$. vulgaris, data kepadatan jenis pertumbuhan sel dalam nutrien MSSIP yang digunakan, disajikan pada Tabel 4 dan dalam bentuk grafik disajikan pada Gambar 2.

Tabel 4.Kepadatan Jenis Fitoplankton Laut Spesies C. vulgaris.

\begin{tabular}{ccccccccccccc}
\hline Nutrien dan & \multicolumn{10}{c}{ Kepadatan Pertumbuhan Fitoplankton (x 104} & sel/mL) \\
\cline { 2 - 14 } Sampel & $\mathbf{1}$ & $\mathbf{2}$ & $\mathbf{3}$ & $\mathbf{4}$ & $\mathbf{5}$ & $\mathbf{6}$ & $\mathbf{7}$ & $\mathbf{8}$ & $\mathbf{9}$ & $\mathbf{1 0}$ & $\mathbf{1 1}$ & $\mathbf{1 2}$ \\
\hline A dan B & 3,0 & 94 & 165 & 381 & 798 & 1047 & 1461 & 2047 & 2514 & 3170 & $\mathbf{3 6 4 9}$ & 3325 \\
C dan K1 & 3,0 & 187 & 502 & 1018 & 1505 & 2014 & 2362 & 2784 & $\mathbf{3 2 4 5}$ & 2570 & 2127 & 1764 \\
D dan B2 & 3,0 & 97 & 115 & 275 & 315 & 441 & 602 & 811 & 945 & 1025 & $\mathbf{1 0 4 7}$ & 1002 \\
E dan B3 & 3,0 & 35 & 69 & 93 & 212 & 419 & $\mathbf{6 3 8}$ & 517 & 374 & 285 & 194 & 102 \\
F dan B4 & 3,0 & 225 & 890 & 1127 & 1509 & 1974 & 2562 & $\mathbf{3 0 9 5}$ & 2384 & 1803 & 1327 & 1164 \\
F1 dan B4-1 & 10 & 397 & 995 & 2120 & 3765 & 6854 & $\mathbf{9 7 0 0}$ & 6905 & 4732 & 2606 & 1801 & 1372 \\
F2 dan B4-2 & 10 & 385 & 984 & 1405 & 2951 & 4092 & 5730 & 7824 & $\mathbf{9 2 9 0}$ & 5847 & 3734 & 2951 \\
G dan K5 & 3,0 & 168 & 359 & 627 & 932 & 1177 & 1396 & 1537 & $\mathbf{1 7 8 5}$ & 1392 & 1025 & 809 \\
I dan B7 (x10) & 1 & 112 & 291 & 397 & 688 & 892 & 1003 & 1021 & $\mathbf{1 1 2 5}$ & 1041 & 980 & 921 \\
\hline
\end{tabular}

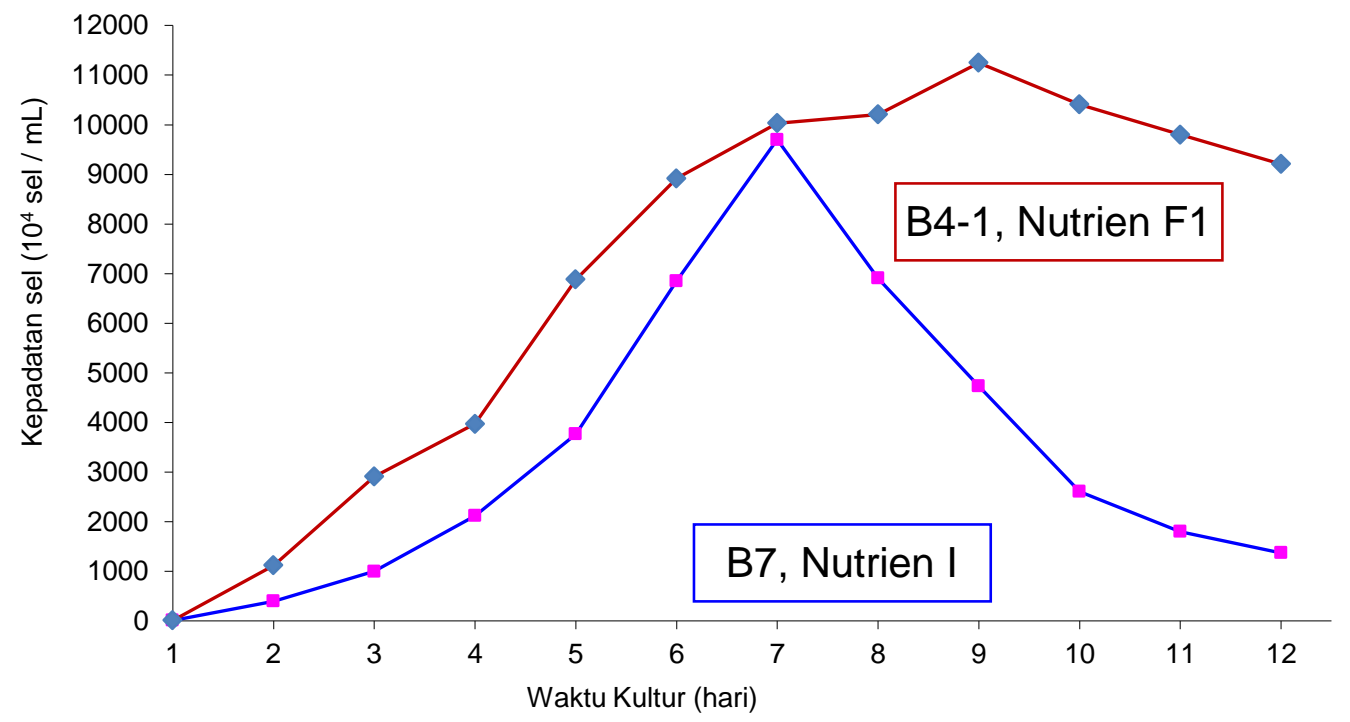

Gambar 2. Grafik Pertumbuhan Sel Spesies C. vulgaris

Berdasarkan data pada Tabel 4 dan Gambar 2, laju kepadatan pertumbuhan sel fitoplankton laut spesies C. vulgaris, diperoleh laju tercepat terjadi dalam 
nutrien $\mathrm{F} 1$ dengan komposisi nutrien yaitu, Urea : Arschat-M : Fe: $\mathrm{Co}: \mathrm{Ni}=6: 3: 9$ : $6: 3$, yang terjadi pada awal hari ke 7 kultur, yaitu $9700 \times 10^{4} \mathrm{sel} / \mathrm{mL}$. Sementara laju akumulasi pertumbuhan sel dengan jumlah terbanyak terjadi dalam nutrien I dengan komposisi nutrien yaitu, Urea : ZA :Fe: $\mathrm{Co}: \mathrm{Ni}=9: 3: 9: 6: 3$, yang dicapai pada awal hari ke 9 kultur, yaitu sekitar $1125 \times 10^{5} \mathrm{sel} / \mathrm{mL}$.

Informasi ini menunjukkan bahwa komponen pupuk urea dalam medium nutrien F1 dengan kehadiran komponen Arschat-M, berpengaruh efektif mempercepat laju kepadatan pertumbuhan sel fitoplankton laut spesies C. vulgaris.Akan tetapi komponen pupuk urea dalam medium nutrien I dengan kehadiran komponen pupuk ZA, berpengaruh efektif memperbanyak akumulasi jumlah sel $C$. vulgaris. Artinya komponen nutrien ion logam $\mathrm{Fe}$, Co dan $\mathrm{Ni}$ yang digunakan efektif mempercepat laju kepadatan pertumbuhan sel spesies fitoplankton laut spesies $C$. vulgaris dalam nutrien F1 dengan keterlibatan komponen pupuk urea dan komponen nutrien Arschat-M, Sedangkan ion logam $\mathrm{Fe}$, Co dan $\mathrm{Ni}$ efektif meningkatkan akumulasi jumlah sel $C$. vulgaris dengan jumlah terbanyak, dalam nutrien I dengan keterlibatan komponen nutrien pupuk ZA.

Untuk fitoplankton laut spesies Spirulina sp., data kepadatan jenis pertumbuhan sel dalam nutrien MSSIP yang digunakan, disajikan pada Tabel 5 dan dalam bentuk grafik disajikan pada Gambar 3.

Berdasarkan data pada Tabel 5 dan Gambar 3, laju kepadatan pertumbuhan sel fitoplankton laut spesies Spirulina sp., diperoleh laju tercepat pada awal hari ke 5 kultur yaitu sekitar $5985 \times 10^{4} \mathrm{sel} / \mathrm{mL}$ yang terjadi dalam nutrien $\mathrm{F} 1$ dengan komposisi nutrien F1 yaitu, Urea : Arschat-M : Fe: Co $: \mathrm{Ni}=6: 3: 9: 6: 3$. Sedangkan laju pertumbuhan sel dengan akumulasi terbanyak yang ditemukan pada awal hari ke 10 kultur yaitu sekitar $1103 \times 10^{5}$ $\mathrm{sel} / \mathrm{mL}$, terjadi dalam nutrien $\mathrm{H}$ dengan komposisi nutrien yaitu, Urea : Arschat$\mathrm{M}:$ Fe: $\mathrm{Co}: \mathrm{Ni}=9: 3: 9: 6: 3$.

Informasi ini menunjukkan bahwa komponen ion logam $\mathrm{Fe}$, Co dan $\mathrm{Ni}$ dengan kehadiran komponen nutrien lain yaitu pupuk urea dan Archta-M membentuk medium F1, dapat mempercepat laju kepadatan pertumbuhan sel fitoplankton laut spesies Spirulina sp. Akan tetapi kondisi berbeda pada penambahan konsentrasi pupuk urea menjadi 1,5 kali ke dalam komponen ion logam Fe, Co, Ni dan nutrien Archta-M membentuk medium nutrien $H$, berpengaruh efektif mempertinggi akumulasi jumlah sel fitoplankton laut spesies Spirulina sp., menjadi hampir dari 2 kali lipat yaitu pada awal hari ke 5 kultur $5985 \times 10^{4} \mathrm{sel} / \mathrm{mL}$ untuk nutrien $\mathrm{F} 1$ dan untuk nutrien $\mathrm{H}$ sekitar $\quad 1103 \times 10^{5}$ $\mathrm{sel} / \mathrm{mL}$ pada awal hari ke 10 kultur. Artinya komponen nutrien ion logam $\mathrm{Fe}$, Co dan $\mathrm{Ni}$ yang digunakan efektif meningkatkan 
laju kepadatan pertumbuhan jumlah sel dan mempertinggi akumulasi jumlah sel fitoplankton laut spesies Spirulina sp., dengan mengatur perbandingan konsentrasi komponen nutrien yaitu pupuk urea.

Tabel 5.Kepadatan Jenis Fitoplankton Laut Spesies Spirulina sp.

\begin{tabular}{|c|c|c|c|c|c|c|c|c|c|c|c|c|}
\hline \multirow{2}{*}{$\begin{array}{c}\text { Nutrien dan } \\
\text { Sampel }\end{array}$} & \multicolumn{12}{|c|}{ Kepadatan Pertumbuhan Fitoplankton (x 10 $\mathrm{sel} / \mathrm{mL}$ ) } \\
\hline & 1 & 2 & 3 & 4 & 5 & 6 & 7 & 8 & 9 & 10 & 11 & 12 \\
\hline A dan I & 3,0 & 38 & 97 & 209 & 453 & 881 & 1305 & 1559 & 1812 & & & 1521 \\
\hline & & 1 & 35 & & 315 & 501 & & 37 & & & & \\
\hline & & 194 & 25 & & 1419 & 1774 & 212 & 2571 & & & & \\
\hline & & 84 & 110 & & 329 & 404 & 532 & 671 & & & & 87 \\
\hline & & 17 & 25 & & & 62 & & 46 & & & & 967 \\
\hline & & 181 & 775 & 35 & 1302 & 1681 & 1939 & 2390 & & 8 & 1831 & 1591 \\
\hline & 1 & 382 & 991 & 2792 & 5985 & 3753 & 2871 & 2154 & 1598 & 982 & 1431 & 1109 \\
\hline & 3,0 & 170 & 339 & & & 1226 & 1541 & 1865 & & & 1011 & 902 \\
\hline & 1 & 70 & 16 & 295 & 410 & 603 & 845 & 983 & & & & 935 \\
\hline I dan I7 (x 10) & 1 & 84 & 239 & 406 & 790 & 921 & 1045 & 1052 & 1017 & 1028 & 1002 & 959 \\
\hline
\end{tabular}

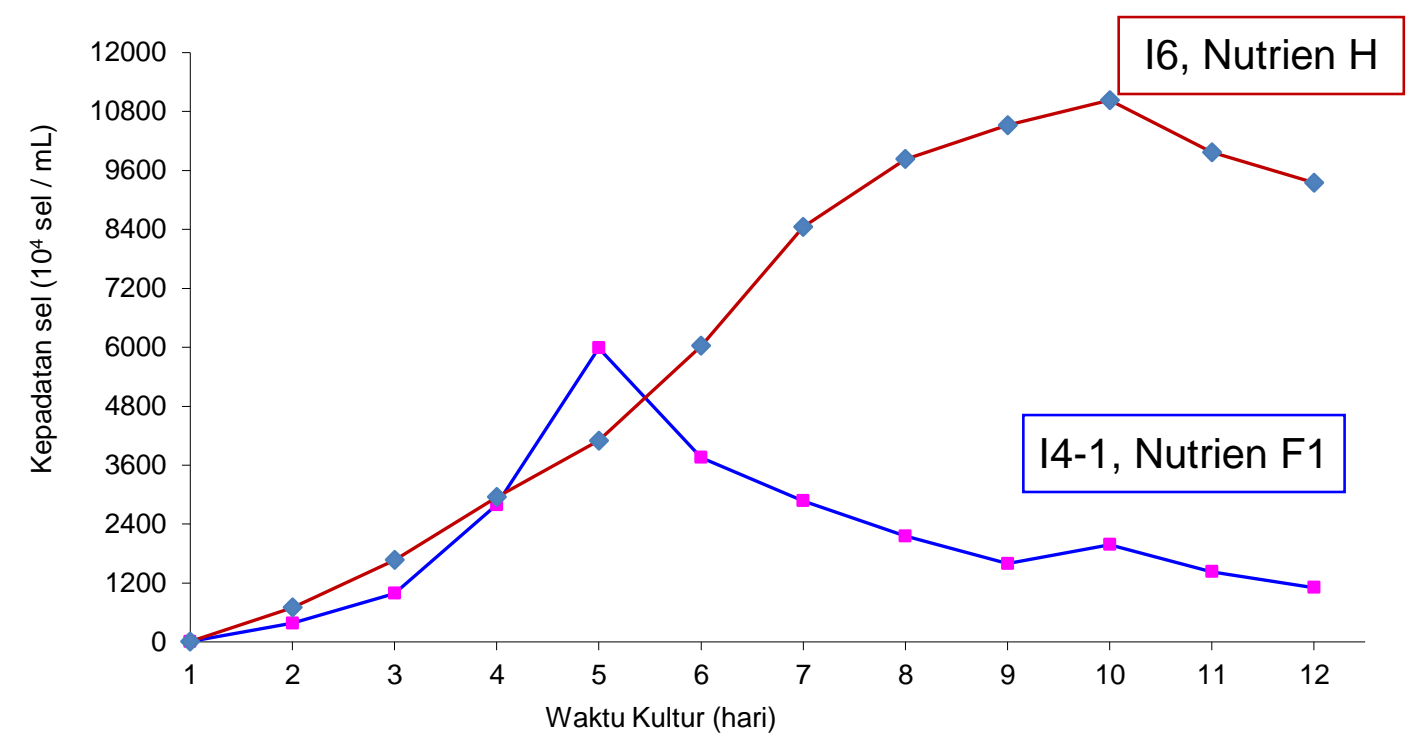

Gambar 3.Grafik Kepadatan Pertumbuhan Sel Fitoplankton Laut Spesies Spirulina sp.

Hasil pembacaan dan analisis kondisi pada Tabel 3 - Tabel 5 dan Gambar 1 - Gambar 3, diperoleh bahwa spesies fitoplankton laut yang dianalisis memperlihatkan hasil yang potensil untuk dilakukan kultur massal agardihasilkan jumlah biomassa yang lebih banyak. Hal lain adalah ketiga spesies fitoplankton tersebut masing-masing memperlihatkan laju kepadatan jenis pertumbuhan tercepat dan laju akumulasi biomassa terbanyak yang memperlihatkan respon terbaik fitoplankton laut dengan nutrient MSSIP.

Secara khusus yang dikaji dalam tahap ini adalah melihat potensi ketiga ion 
logam $\mathrm{Fe}$, Codan $\mathrm{Ni}$ dan sekaligus menjawab pertanyaan tentang potensi ketiga ion logam tersebut, terutama ion logam $\mathrm{Ni}$ (nikel) sebagai logam berat berbahaya, namun jika ion logam ini digunakan pada konsentrasi yang sesuai akan bermanfaat khususnya untuk pertumbuhan fitoplankton laut (Nontji, 2008). Untuk jangka panjang, pengkajian tetap terus dilakukan agar ditemukan komposisi nutrien yang lebih unggul dan lebih efisien sebagai medium pertumbuhan fitoplankton laut, dengan memperhitungkan salah satu aspek penting dalam pengembangannya yaitu nilai ekonomis pada nutrien yang dikaji.

Potensi interaksi ketiga ion logam $\mathrm{Fe}$, Co dan $\mathrm{Ni}$ yang digunakan sebagai komponen nutrien, dianalisis pola perbandingannya pada ketiga fitoplankton tersebut yaitu D. salina, C. vulgaris,dan Spirulina sp., menggunakan nutrien F1 sebagai nutrien yang memperlihatkan respon laju akumulasi dan laju kecepatan spesifik fitoplankton laut terbaik. Konsentrasi ketiga ion logam $\mathrm{Fe}$, Co dan $\mathrm{Ni}$ yang digunakan, masing-masing adalah: 3, 2 dan 1 ppm. Komposisi nutrien medium sebelum kultur ditentukan konsentrasinya, komposisi medium setelah kultur dianalisis dengan XRF, ketiga ion logam $\mathrm{Fe}$, Codan $\mathrm{Ni}$ dianalisis dengan AAS, hasilnya pada Tabel 6 dan Tabel 7.
Tabel 6. Komposisi Nutrien Medium MSSIP Jenis Nutrien F1 sebelum kultur.

\begin{tabular}{clc}
\hline No. & \multicolumn{1}{c}{$\begin{array}{c}\text { Komponen } \\
\text { Nutrien Medium } \\
\text { MSSIP }\end{array}$} & $\begin{array}{c}\text { Konsentrasi } \\
\text { (ppm) }\end{array}$ \\
\hline 1 & $\mathrm{NaCl}$ & 300 \\
2 & $\mathrm{MgSO}_{4} .7 \mathrm{H}_{2} \mathrm{O}$ & 5 \\
3 & $\mathrm{KNO}_{3}$ & 2 \\
4 & $\mathrm{KH}_{2} \mathrm{PO}_{4}$ & 5 \\
5 & $\mathrm{CaCl}_{2} \cdot 6 \mathrm{H}_{2} \mathrm{O}$ & 5 \\
6 & $\mathrm{H}_{3} \mathrm{BO}_{3}$ & 200 \\
7 & $\mathrm{ZnSO}_{4} \cdot 7 \mathrm{H}_{2} \mathrm{O}$ & 1 \\
8 & $\mathrm{MnSO}_{4} \cdot 4 \mathrm{H}_{2} \mathrm{O}$ & 1 \\
9 & $\mathrm{CuSO}_{4} .5 \mathrm{H}_{2} \mathrm{O}$ & 0.1 \\
10 & $\mathrm{CoCl}_{2} \cdot 6 \mathrm{H}_{2} \mathrm{O}$ & 0.2 \\
11 & $\left(\mathrm{NH}_{4}\right)_{6} \mathrm{Mo}_{7} \mathrm{O}_{24} \cdot 4 \mathrm{H}_{2} \mathrm{O}$ & 0.2 \\
12 & $\mathrm{NaFeEDTA}_{1} \mathrm{ADT}$ & 25 \\
13 & $\mathrm{NaSiO}_{3} \cdot 9 \mathrm{H}_{2} \mathrm{O}$ & 10 \\
14 & $\mathrm{Campuran} \mathrm{Vitamin}_{15}$ & 1 \\
16 & $\mathrm{HCl}$ & 50 \\
\hline
\end{tabular}

Tabel 7. Komposisi lon logam $\mathrm{Fe}, \mathrm{Co}, \mathrm{Ni}$ dan Komponen Nutrien MSSIP Jenis F1.

\begin{tabular}{|c|c|c|c|}
\hline & Jenis & Konsentrasi & $\begin{array}{c}\text { Konsentrasi } \\
\text { Akhir }\end{array}$ \\
\hline No. & Nutrien & $\begin{array}{c}\text { Awal } \\
\text { (ppm) }\end{array}$ & $\begin{array}{cc}\text { XRF } & \text { AAS } \\
(\% b / b) & (p p m)\end{array}$ \\
\hline
\end{tabular}

\begin{tabular}{|c|c|c|c|c|}
\hline \multicolumn{5}{|c|}{ A. Fitoplankton laut D. salina } \\
\hline 1 & $\mathrm{Cl}$ & - & 84,980 & - \\
\hline 2 & $\mathrm{Ca}$ & - & 6,600 & - \\
\hline 3 & K & - & 5,490 & - \\
\hline 4 & $\mathrm{Fe}$ & 3 & - & 0,697 \\
\hline 5 & Co & 2 & - & 0,396 \\
\hline 6 & $\mathrm{Ni}$ & 1 & - & 0,241 \\
\hline \multicolumn{5}{|c|}{ B. Fitoplankton laut C. vulgaris } \\
\hline 1 & $\mathrm{Cl}$ & - & 59,010 & - \\
\hline 2 & $\mathrm{Ca}$ & - & 3,190 & - \\
\hline 3 & K & - & 3,800 & - \\
\hline 4 & $\mathrm{Mg}$ & & 31,530 & - \\
\hline 5 & $\mathrm{Fe}$ & 3 & - & 0,795 \\
\hline 6 & Co & 2 & - & 0,498 \\
\hline 7 & $\mathrm{Ni}$ & 1 & - & 0,257 \\
\hline \multicolumn{5}{|c|}{ C. Fitoplankton laut Spirulina sp. } \\
\hline 1 & $\mathrm{Cl}$ & - & 84,860 & - \\
\hline 2 & $\mathrm{Ca}$ & - & 6,650 & - \\
\hline 3 & K & - & 5,540 & - \\
\hline 4 & $\mathrm{Fe}$ & 3 & - & 0,791 \\
\hline 5 & Co & 2 & - & 0,571 \\
\hline 6 & $\mathrm{Ni}$ & 1 & - & 0,202 \\
\hline
\end{tabular}


Berdasarkan Tabel 6 dan Tabel 7, komponen yang terdeteksi oleh XRF (X Ray Fluorescence) adalah unsur $\mathrm{Cl}, \mathrm{K}$, $\mathrm{Mg}, \mathrm{Ca}$, dan beberapa unsur lainnya, sedangkan ion logam $\mathrm{Fe}$, Codan $\mathrm{Ni}$ tidak terdeteksi. Untuk melengkapi hasil analisis ion logam $\mathrm{Fe}$, Codan $\mathrm{Ni}$ dalam nutrien setelah kultur, maka digunakan pengukuran dengan instrumen AAS pada sampel yang sama.

Penggunaan ion logam $\mathrm{Fe}$, Co dan $\mathrm{Ni}$ pada keenam jenis fitoplankton laut yang potensial berdasarkan hasil yang diperoleh selama kultur berlangsung pada ketiga spesies fitoplankton laut, yaitu: $D$. salina, C. vulgaris, dan Spirulina sp., adalah: Ion logam $\mathrm{Fe}>\mathrm{Co}>\mathrm{Ni}$ dengan ratarata perbandingan ion logam $\mathrm{Fe}: \mathrm{Co}: \mathrm{Ni}$ $=9: 3: 1$.

Kondisi ini menunjukkan bahwa ion logam $\mathrm{Fe}$, Co dan Ni dibutuhkan dalam jumlah yang sesuai dengan jenis fitoplankton laut yang digunakan.Untuk menentukan komposisi perbandingan terbaik ion logam $\mathrm{Fe}$, Co dan $\mathrm{Ni}$ dalam nutrien, dilakukan analisis pola kepadatan jenis pertumbuhan fitoplankton laut pada beberapa macam nutrien medium MSSIP yang digunakan.

\section{Interaksi Ion Logam $\mathrm{Fe}$, Co dan $\mathrm{Ni}$ dalam Nutrien MSSIP Pada Kultur Sel Fitoplankton Laut}

Interaksi ketiga ion logam $\mathrm{Fe}$, Co dan $\mathrm{Ni}$ tersebut pada komposisi nutrien MSSIP terhadap spesies fitoplankton laut dalam menstimulasi laju pertumbuhan dan tingkat kepadatan akumulasinya, maka digunakan data kepadatan jenis pertumbuhan sel spesies fitoplankton laut dalam beberapa jenis nutrien MSSIP dengan membandingkan laju kepadatan jenis pertumbuhan spesies fitoplankton laut kedalam masing-masing nutrien MSSIP yang digunakan.

Perbandingan laju kepadatan jenis spesies fitoplankton laut dalam nutrien MSSIP Jenis A, B, C dan nutrien D diperlihatkan pada Tabel 8.

Tabel 8.Kepadatan Jenis Sel Fitoplankton Laut D. salina dalam Nutrien A, Nutrien B, Nutrien C dan Nutrien D.

\begin{tabular}{|c|c|c|c|c|c|c|c|c|c|c|c|}
\hline \multirow{2}{*}{$\begin{array}{c}\text { JENIS } \\
\text { FITOPLANKTON }\end{array}$} & \multicolumn{11}{|c|}{ Kepadatan Pertumbuhan Fitoplankton (x $10^{4} \mathrm{sel} / \mathrm{mL}$ ) } \\
\hline & 1 & 23 & 4 & 5 & 6 & 7 & 8 & 9 & 10 & 11 & 12 \\
\hline \multicolumn{12}{|c|}{ Nutrien A (Urea : Fe = $3: 9$ ) } \\
\hline A $\quad$ D. salina & 2,5 & 1335 & 105 & 398 & 825 & 953 & 1106 & 1245 & 1328 & 1201 & 1103 \\
\hline \multicolumn{12}{|c|}{ Nutrien B (Urea : Fe : Co = $3: 9: 6$ ) } \\
\hline KA D. salina & 2,5 & 1430 & 172 & 218 & 345 & 413 & 518 & 635 & 827 & 720 & 562 \\
\hline \multicolumn{12}{|c|}{ Nutrien C (Urea : Ni : Fe = $3: 1: 9)$} \\
\hline A1 D. salina & 2,5 & 102435 & 852 & 1117 & 1443 & 1563 & 1718 & 1525 & 1183 & 914 & 825 \\
\hline \multicolumn{12}{|c|}{ Nutrien D (Urea : Fe : Co = 3:9:9) } \\
\hline A2 D. salina & 2,5 & 80103 & 252 & 317 & 415 & 593 & 688 & 835 & 980 & 994 & 921 \\
\hline
\end{tabular}

Berdasarkan data pada Tabel 8 tersebut, ditemukan bahwa fitoplankton laut spesies $D$. salina pada nutrien $A$ memiliki kepadatan tertinggi sekitar 1328 x $10^{4} \mathrm{sel} / \mathrm{mL}$, ditemukan pada awal hari ke 10 kultur. Pada nutrien $B$ memiliki 
kepadatan tertinggi sekitar $827 \times 10^{4}$ $\mathrm{sel} / \mathrm{mL}$, ditemukan pada awal hari ke 10 kultur. Pada nutrien $\mathrm{C}$ memiliki kepadatan tertinggi sekitar $1718 \times 10^{4} \mathrm{sel} / \mathrm{mL}$, ditemukan pada awal hari ke 8 kultur. Pada nutrien $D$ memiliki kepadatan tertinggi sekitar $994 \times 10^{4} \mathrm{sel} / \mathrm{mL}$, ditemukan pada awal hari ke 11 kultur.

Informasi ini menunjukkan bahwa ion logam $\mathrm{Fe}$ dan $\mathrm{Ni}$ dibutuhkan oleh $D$. salina dalam pertumbuhannya, oleh karena dengan penambahan ion logam $\mathrm{Ni}$ 1/9 bagian dari ion logam Fe ke dalam nutrien $\mathrm{A}$ membentuk nutrien $\mathrm{C}$ maka akumulasi kepadatan selnya meningkat. Kondisi sebaliknya terjadi penurunan akumulasi sel fitoplankton laut $D$. salinapada nutrien B yang ditambahkan ion logam Co 2/3 bagian dari ion logam Featau pada nutrien $D$ dengan penambahan ion logam Cosama dengan ion logam Fe.

Selanjutnya pada Tabel 9, fitoplankton laut $C$. gracilis memiliki kepadatan tertinggi sekitar $1114 \times 10^{4}$ sel/mL dalam nutrien A pada awal hari ke 8 kultur. Untuk nutrien B, kepadatan tertinggi pada awal hari ke 11 kultur sekitar $825 \times 10^{4} \mathrm{sel} / \mathrm{mL}$, dalam nutrien C diperoleh kepadatan tertinggi sekitar $1392 \times 10^{4} \mathrm{sel} / \mathrm{mL}$, pada awal hari ke 8 kultur, dan dalam nutrien $D$ memiliki kepadatan tertinggi sekitar $415 \times 10^{4}$ $\mathrm{sel} / \mathrm{mL}$, pada awal hari ke 12 kultur.

Tabel 9. Kepadatan Jenis sel fitoplankton laut $C$. gracilis dalam nutrien $A$, nutrien $B$, nutrien C dan nutrien $\mathrm{D}$.

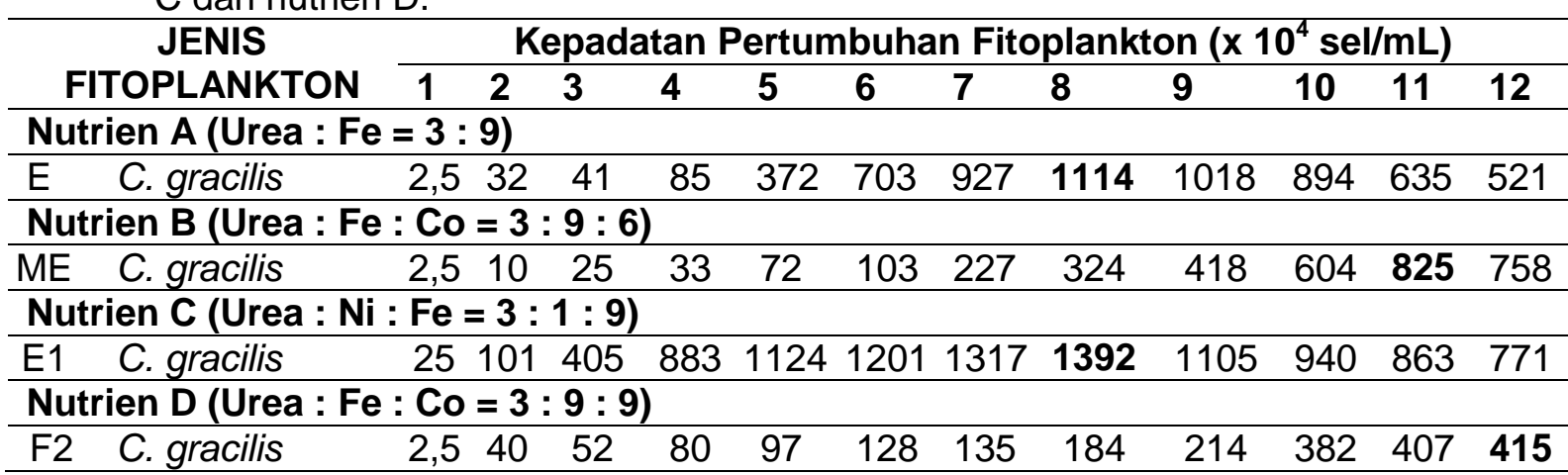

Informasi yang diperoleh pada Tabel 9, menunjukkan bahwa ion logam Fe dan $\mathrm{Ni}$ juga sangat dibutuhkan oleh fitoplankton laut $C$. gracilis dalam pertumbuhannya oleh karena diperoleh akumulasi sel yang rata-rata lebih banyak pada nutrien $\mathrm{C}$, jika dibandingkan dengan kultur pada nutrien A, B dan D. Bahkan penambahan ion logam Co kedalam nutrien $B$, menunjukkan penurunan akumulasi pertumbuhan sel menjadi sekitar $1 / 2$ bagian dan juga menurun 1/3 bagian dalam nutrien $D$. 
Tabel 10. Kepadatan Jenis sel fitoplankton laut Spirulina sp. dalam nutrien A, nutrien B, nutrien $\mathrm{C}$ dan nutrien $\mathrm{D}$.

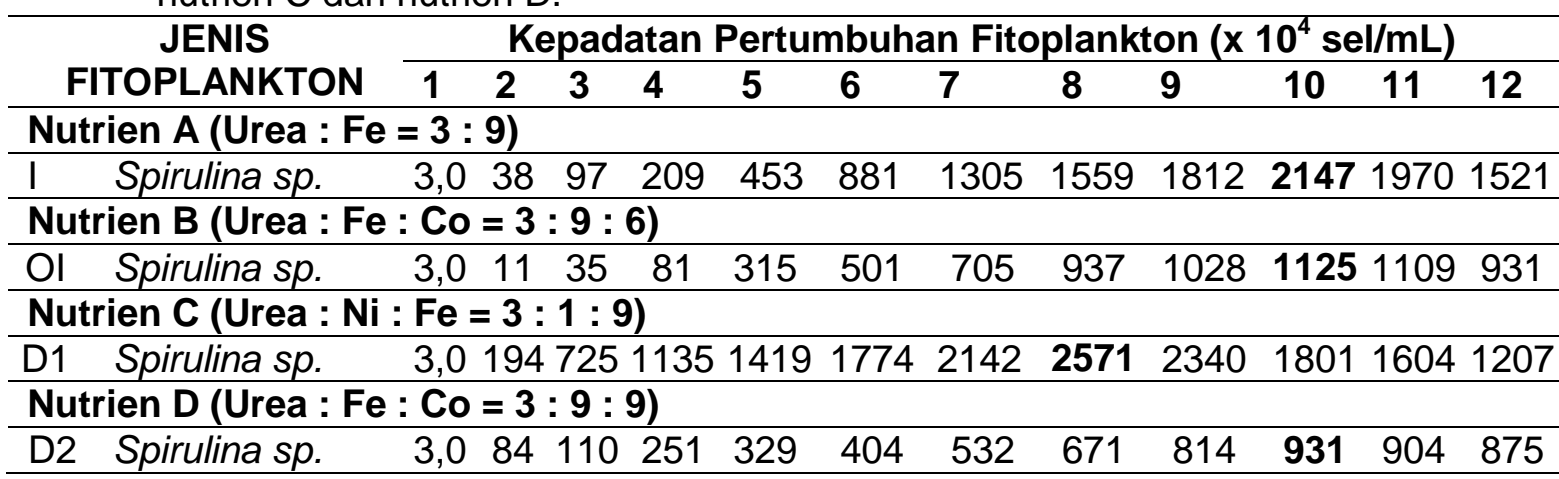

Berdasarkan data pada Tabel 10, ditemukan bahwa fitoplankton laut spesies Spirulina sp., memiliki kepadatan tertinggi masing-masing sekitar $2147 \times 10^{4} \mathrm{sel} / \mathrm{mL}$ dalam nutrien $A$ pada awal hari ke 10 kultur, sekitar $1125 \times 10^{4} \mathrm{sel} / \mathrm{mL}$ dalam nutrien B pada awal hari ke 10 kultur, dalam nutrien $\mathrm{C}$ sekitar $2571 \times 10^{4} \mathrm{sel} / \mathrm{mL}$ pada awal hari ke 8 kultur, dan dalam nutrien $D$ memiliki kepadatan tertinggi sekitar $931 \times 10^{4} \mathrm{sel} / \mathrm{mL}$, yang ditemukan pada awal hari ke 10 kultur.

Informasi pada Tabel 10 ini, menunjukkan bahwa ion logam $\mathrm{Fe}$ dan $\mathrm{Ni}$ sangat dibutuhkan oleh fitoplankton laut Spirulina $s p$. dalam pertumbuhannya, oleh karena dengan penambahan ion logam $\mathrm{Ni}$ 1/9 bagian ion logam $\mathrm{Fe}$ dalam nutrien $\mathrm{C}$ maka akumulasi kepadatan selnya meningkat pesat, jika dibandingkan dalam nutrien A, B dan D. sebaliknya pada nutrien $B$ dan $C$ yang memperlihatkan bahwa ion logam Co yang ditambahkan kedalam nutrien $\mathrm{B}$ dan $\mathrm{C}$, malah menurunkan akumulasi sel Spirulina sp.

Berdasarkan informasi pada Tabel 8 - Tabel 10, menunjukkan bahwa ion logam Ni sangat dibutuhkan oleh fitoplankton laut dalam pertumbuhannya, oleh karena dengan penambahan $1 / 9$ bagian dari ion logam Fe, akumulasi sel fitoplankton laut rata-rata lebih banyak jika dibandingkan dengan penambahan ion logam Co sebanyak 2/3 bagian dari ion logam $\mathrm{Fe}$.

Kondisi ini menunjukan bahwa ke tiga spesies fitoplankton laut yaitu: Dunaliella salina, Chlorellavulgaris dan Spirulina sp., memperlihatkan respon yang berbeda terhadap nutrient yang digunakan, hal ini oleh karena adanya perbedaan afinitasnya dengan ketiga ion logam $\mathrm{Fe}$, Co dan $\mathrm{Ni}$ yang dianalisis termasuk perbedaan morfologi fitoplankton laut. Akan tetapi informasi ilmiah ini telah menunjukkan bahwa ion logam $\mathrm{Fe}$, Co dan Ni pada jumlah tertentu sangat dibutuhkan pada pertumbuhan fitoplankton laut, walaupun pengaruhnya berbeda satu dengan yang lain. Bahkan dengan kehadiran ion logam $\mathrm{Ni}$ sebagai logam berat pada nutrien $\mathrm{C}$, memperlihatkan rata-rata pertumbuhan sel fitoplankton laut lebih tinggi jika dibandingkan dengan kehadiran ion logam Co pada nutrien $\mathrm{B}$, dan juga dalam nutrien $D$, dimana dalam nutrien $D$ konsentrasi 
ion logam Co yang digunakan 1,5 kali lebih besar dari nutrien $B$, akan tetapi rata-rata pertumbuhan sel fitoplankton laut masih lebih tinggi pada nutrien $\mathrm{C}$ yang diintegrasi dengan ion logam $\mathrm{Ni}$, walaupun hanya 1/9 bagian dari ion logam Fe.

Artinya untuk keempat nutrien MSSIP yang digunakan, yaitu jenis nutrien A, B, C dan D, memperlihatkan rata-rata kepadatan jenis terbesar untuk pertumbuhan sel fitoplankton laut, ditemukan pada nutrien C. Namun demikian ketiga ion logam yang digunakan dalam komposisi nutrien MSSIP yaitu ion logam $\mathrm{Fe}$, Co dan $\mathrm{Ni}$, merupakan ion logam yang dibutuhkan oleh fitoplankton laut, akan tetapi harus dengan menggunakan perbandingan yang sesuai. Perbandingan terbaik yang dapat digunakan pada pertumbuhan sel spesies fitoplankton laut untuk ke tiga ion logam yaitu:Fe:Co:Ni adalah $9: 6: 1$, dengan catatan menggunakan urea sebagai komponen tambahan sebanyak 3 bagian. Perbandingan ini akan diuji lagi dengan komposisi nutrien MSSIP yang berbeda yaitu nutrien $E$ dan $F$ untuk mencari komposisi terbaik perbandingan ketiga ion logam $\mathrm{Fe}$, Co dan $\mathrm{Ni}$.

Perbandingan laju kepadatan jenis fitoplankton laut dalam nutrien MSSIP jenis nutrien $\mathrm{E}$ (komposisi, urea : Fe : Co : $\mathrm{Ni}=6: 9: 6: 1)$ dan nutrien $\mathrm{F}$ (komposisi, urea : Fe : Co : $\mathrm{Ni}=6: 9: 6: 3)$, diperlihatkan pada Tabel 11.

Tabel 11. Kepadatan Jenis Sel Fitoplankton Laut dalam Nutrien E dan Nutrien F

\begin{tabular}{|c|c|c|c|c|c|c|c|c|c|c|c|c|}
\hline \multirow{2}{*}{$\begin{array}{c}\text { JENIS } \\
\text { FITOPLANKTON }\end{array}$} & \multicolumn{12}{|c|}{ Kepadatan Pertumbuhan Fitoplankton (x $10^{4} \mathrm{sel} / \mathrm{mL}$ ) } \\
\hline & 1 & 2 & 3 & 4 & 5 & 6 & 7 & 8 & 9 & 10 & 11 & 12 \\
\hline \multicolumn{13}{|l|}{ Nutrien E } \\
\hline A3 D. salina & 2,5 & 11 & 29 & 35 & 44 & 58 & 88 & 120 & 139 & 115 & 85 & 77 \\
\hline C. vulgaris & 3,0 & 35 & 69 & 93 & 212 & 419 & 638 & 517 & 374 & 285 & 194 & 102 \\
\hline K3 Spirulina sp. & 3,0 & 17 & 25 & 35 & 45 & 62 & 114 & 246 & 395 & 791 & 985 & 967 \\
\hline \multicolumn{13}{|l|}{ Nutrien F } \\
\hline A4 D. salina & 2,5 & 173 & 535 & 932 & 1125 & 1343 & 1518 & 1690 & $142 !$ & 130 & 1034 & 821 \\
\hline C. vulgaris & 3,0 & 225 & 890 & 1127 & 1509 & 1974 & 2562 & 3095 & 2384 & 180 & 1327 & 1164 \\
\hline Spirulina sp. & 3,0 & 181 & 775 & 1085 & 1302 & 1681 & 1939 & 2390 & 2581 & 2208 & 1831 & 1591 \\
\hline
\end{tabular}

Berdasarkan pada Tabel 11, laju kepadatan jenis tertinggi untuk spesies $D$. salina, C. vulgaris, danSpirulina sp., ditemukan dalam nutrien $F$ jika dibandingkan dengan ke delapan spesies fitoplankton laut tersebut apabila dilakukan kultur dalam nutrien E.Informasi ini menunjukkan bahwa laju kepadatan jenis tertinggi untuk spesies $D$. salina ditemukan pada nutrien $F$ yaitu sekitar
$1690 \times 10^{4} \mathrm{sel} / \mathrm{mL}$ awal hari ke 8 kultur, apabila dibandingkan dengan nutrien $E$ hanya sekitar $139 \times 10^{4} \mathrm{sel} / \mathrm{mL}$, yang ditemukan pada awal hari ke 9 kultur. Kondisi yang sama untuk spesies lain juga dapat dibandingkan dengan hasil yang signifikan. Hal ini menunjukkan bahwa penambahan jumlah ion logam $\mathrm{Ni}$ dalam nutrien $E$ menjadi $1 / 3$ bagian dari ion logam $\mathrm{Fe}$ dalam nutrien $\mathrm{F}$, pertumbuhan 
fitoplankton laut malah meningkat menjadi semakin pesat. Kondisi ini sesuai dengan kepadatan jenis sel fitoplankton laut yang diperoleh menjadi semakin besar dan bahkan mencapai akumulasi sel lebih dari 10 kali, dengan tingkat akumulasi tertinggi yang ditemukan lebih cepat 1 hari pada nutrien $F$ jika dibandingkan dengan nutrien $\mathrm{E}$.

Kondisi ini mengindikasikan bahwa nutrien $\mathrm{F}$ lebih baik dari nutrien $\mathrm{E}$ dimana ion logam $\mathrm{Ni}$ yang digunakan dalam nutrien $F$, komposisinya 3 kali lebih besar dari komposisi dalam nutrien $E$. Berdasarkan hasil yang diperoleh setelah perlakuan kultur dengan nutrien $\mathrm{E}$ dan nutrien $F$, perbandingan komposisi ketiga ion logam $\mathrm{Fe}$, Co dan $\mathrm{Ni}$ yang terbaik untuk digunakan dalam kultur spesies fitoplankton laut uji adalah $9: 6: 3$.
Untuk lebih memastikan komposisi terbaik perbandingan ketiga ion logam $\mathrm{Fe}$, Co dan Ni yaitu (9:6:3), maka dilakukan analisis pembanding pada kultur dalam nutrien MSSIP yang lain yaitu pada nutrien $F 1$ dan nutrien F2. Komposisi masing-masing nutrien $\mathrm{F} 1$ dan nutrien $\mathrm{F} 2$ yang digunakan adalah: Nutrien F1 (Urea : Arschat-M : Fe : Ni : Co = $6: 3: 9: 3: 6)$ dan nutrien F2 (Urea : Arschat-M : $\mathrm{Fe}: \mathrm{Ni}$ $:$ Co $=6: 3: 9: 3: 12$ ).

Komposisi nutrien F2 menggunakan ion logam Co, konsentrasinya 2 kali lebih besar jika dibandingkan dengan nutrien $\mathrm{F} 1$, sementara komposisi yang lain dibuat konstan. Hasil laju kepadatan jenis fitoplankton laut dalam nutrien MSSIP jenis nutrien $\mathrm{F} 1$ dan nutrien $\mathrm{F} 2$ diperlihatkan pada Tabel 12.

Tabel 12. Kepadatan Jenis sel fitoplankton laut dalam Nutrien F1 dan dalam Nutrien F2

\begin{tabular}{|c|c|c|c|c|c|c|c|c|c|c|c|c|}
\hline \multirow{2}{*}{$\begin{array}{c}\text { JENIS } \\
\text { FITOPLANKTON }\end{array}$} & \multicolumn{12}{|c|}{ Kepadatan Pertumbuhan Fitoplankton ( $\times 10^{4} \mathrm{sel} / \mathrm{mL}$ ) } \\
\hline & 1 & 2 & 3 & 4 & 5 & 6 & 7 & 8 & 9 & 10 & 11 & 12 \\
\hline \multicolumn{13}{|c|}{ Nutrien F1 (Urea : Arschat-M : Fe : Ni : Co = $6: 3: 9: 3: 6$ ) } \\
\hline A4-1 D. salina & 10 & 231 & 714 & 1213 & 1545 & 2192 & 1321 & 917 & 775 & 701 & 854 & 816 \\
\hline C. vulgaris & 10 & 397 & 995 & 212 & & 6854 & 9700 & & 4732 & & & . \\
\hline 14-1 Spirulina sp. & 10 & 382 & 991 & 2792 & 5985 & 3753 & 2871 & 2154 & & & & \\
\hline \multicolumn{13}{|c|}{ Nutrien F2 (Urea : Arschat-M : Fe : Ni : Co = $6: 3: 9: 3: 12$ ) } \\
\hline A4-2 D. salina & 10 & 214 & 595 & 931 & 1128 & 1305 & 1411 & 16 & & & & \\
\hline C. vulgaris & 10 & 385 & 984 & 1405 & 2951 & $40 \varsigma$ & 5730 & & 9290 & & & 295 \\
\hline Spirulina sp. & 10 & 112 & 390 & 769 & 1071 & 1191 & 1335 & 1452 & 1306 & 1104 & 1013 & 89 \\
\hline
\end{tabular}

Berdasarkan Tabel 12, diperoleh perbandingan laju kepadatan jenis spesies fitoplankton laut yang digunakan pada kultur dengan medium MSSIP jenis nutrien $\mathrm{F} 1$ dan nutrien $\mathrm{F} 2$, memiliki perbedaan yang jelas dan sangat nyata. Laju kepadatan pertumbuhan dan laju akumulasi sel fitoplankton laut pada kulturdengan medium nutrien $\mathrm{F} 1$ lebih besar dibandingkan dengan menggunakan nutrien F2 terhadap spesies fitoplankton laut yang dijadikan sampel. Akumulasi kepadatan sel fitoplankton laut $D$. salina tertinggi pada awal hari ke 6 yaitu $2192 \times 10^{4} \mathrm{sel} / \mathrm{mL}$ dalam nutrien $F 1$ dan dalam nutrien $F 2$ 
pada awal hari ke 9 kultur hanya sekitar $1892 \times 10^{4} \mathrm{sel} / \mathrm{mL}$.

Kondisi ini menunjukkan bahwa nutrien $\mathrm{F} 1$ yang digunakan dengan komposisi komponennya adalah Urea : Arschat-M : Fe : Ni : Co = $6: 3: 9: 3: 6$, lebih baik jika dibandingkan dengan nutrien F2 dengan komposisi Urea : Arschat-M : Fe : Ni : Co = $6: 3: 9: 3: 12$. Kedua nutrien ini memiliki komponen yang sama, hanya konsentrasi ion logam Co yang digunakan dalam nutrien F2 adalah 2 kali lebih besar dibandingkan dalam nutrien $\mathrm{F} 1$. Hal ini menunjukkan bahwa dengan peningkatan konsentrasi ion logam Co menjadi 2 kali lebih besar, menghasilkan penurunan laju kepadatan pertumbuhan dan laju akumulasi sel fitoplankton laut. Berdasarkan informasi ini disimpulkan bahwa perbandingan konsentrasi ion logam $\mathrm{Fe}$, Co dan Ni yang terbaik untuk digunakan dalam kultur pertumbuhan fitoplankton laut adalah:9:6

: 3, dengan catatan tetap diintegrasikan dengan komponen lain, yaitu pupuk urea dan nutrien Arschat-M.

Integrasi ion logam $\mathrm{Fe}$, Co dan $\mathrm{Ni}$ pada biomassa fitoplankton laut dengan perbandingan terbaik untuk ion logam Fe:Co:Ni = $9: 6: 3$, yang ditemukan dalam penelitian ini memiliki pola interaksi yang berbanding lurus dengan perbandingan yang ditemukan olehMorel(2008). Interaksi ion logam $\mathrm{Fe}^{2+}$ relatif lebih besar jika dibandingkan dengan ion logam $\mathrm{Co}^{2+}$ dan interaksi ion logam $\mathrm{Co}^{2+}$ relatif lebih besar dari ion logam $\mathrm{Ni}^{2+}$. Pola interaksi ion logam $\mathrm{Fe}$, Co dan Ni terhadap ligan-ligan yang ada dalam biomassa fitoplankton laut, disajikan pada Gambar 4, yang memperlihatkan bahwa urutan kekuatan pola interaksi ion logam tersebut secara berurutan adalah sebagai berikut yaitu: $\mathrm{Fe}>\mathrm{Co}>\mathrm{Ni}$.

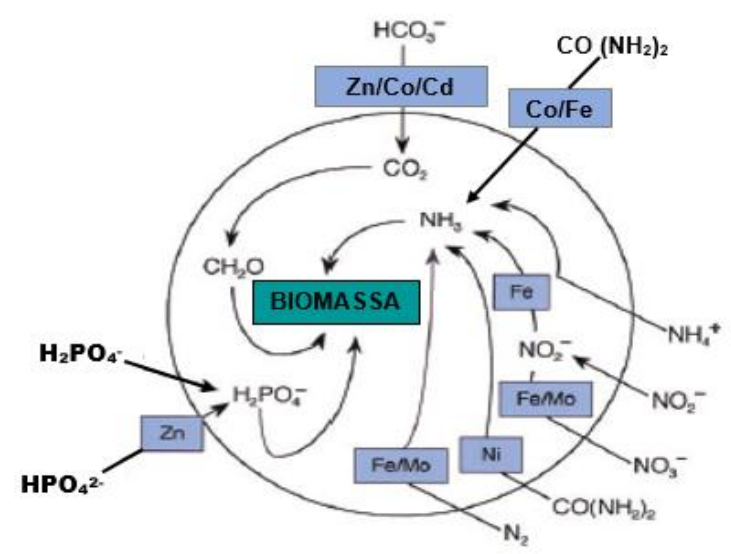

Gambar 4. Pola interaksi ion logam $\mathrm{Fe}$, Co dan Ni terhadap ligan pada biomassa fitoplankton laut (Morel, 2008, Kasim, 2016).

Hal ini dapat dijelaskan dengan baik oleh karena sesuai dengan teori ikatan logam ligan dalam deret kekuatan ligan dalam berikatan dengan ion logam, yang juga sesuai dengan teori ikatan valensi, teori medan ligan, dan teori orbital molekul. Ion logam $\mathrm{Fe}^{2+}$ memiliki 4 orbital, ion logam $\mathrm{Co}^{2+} 3$ orbital dan ion logam $\mathrm{Ni}^{2+} 2$ orbital pada sub kulit $3 \mathrm{~d}$ yang tidak berpasangan dalam bentuk high spin kompleks yang berikatan dengan ligan lemah. Apabila berbentuk low spin kompleks, ion logam $\mathrm{Fe}^{2+}$ tidak memiliki orbital, ion logam $\mathrm{Co}^{2+} 1$ orbital dan ion logam $\mathrm{Ni}^{2+} 2$ orbital pada sub kulit $3 d$ yang tidak berpasangan apabila berikatan 
dengan ligan kuat. (Sugiarto, 2012;Sjahrul, 2010; Cotton, 1989).Berdasarkan informasi ini menunjukkan bahwa nutrien $\mathrm{F} 1$ lebih baik dari nutrien F2, terhadap sampel fitoplankton laut yang digunakan yaitu $D$. salina, C. vulgaris, dan Spirulina sp.

\section{Kultur Germinasi dan Penentuan Laju Pertumbuhan Spesifik}

Kultur fitoplankton laut pada tahap germinasi sebelum kultur massal yang merupakan tahap pengembangbiakan dan prakondisi sel fitoplankton laut sebelum kultur massal. Pada tahap ini laju kepadatan jenis pertumbuhan spesies fitoplankton laut uji berdasarkan jenis nutrien yang telah ditemukan, dipakai untuk menentukan laju kepadatan pertumbuhan spesifik, waktu kultur terbaik dan akumulasi sel fitoplankton laut terbanyak. Hasilnya diperlihatkan pada Tabel 13.

Artinya ion logam $\mathrm{Fe}$, Co dan $\mathrm{Ni}$ berdasarkan data pada Tabel 12, dapat menstimulus laju akumulasi terbanyak pada fitoplankton laut spesies $C$. vulgaris dengan bantuan komponen pupuk urea dan pupuk ZA, yaitu $1,125 \times 10^{8} \mathrm{sel} / \mathrm{mL}$. Informasi lain adalah laju kepadatan jenis pertumbuhan tertinggi sekitar 0,0667 $\mathrm{sel} / \mathrm{mL} / J a m$ yang ditemukan pada hari ke 4 kultur pada spesies fitoplankton laut spesies Spirulina sp.,menggunakan nutrien MSSIP (nutrien F1) dengan komposisi nutrien (Urea : Arschat-M: Fe : $\mathrm{Ni}:$ Co $=6: 3: 9: 3: 6)$. Hal ini berarti bahwa ion logam $\mathrm{Fe}$, Co dan $\mathrm{Ni}$ dalam nutrien MSSIP dapat mempercepat laju kepadatan pertumbuhan fitoplankton laut dengan keterlibatan komponen lain yaitu pupuk urea dan nutrien Arschat-M.

Tabel 13.Laju Kepadatan Pertumbuhan Spesifik Tertinggi dan Akumulasi Terbanyak Biomassa Sel Fitoplankton Laut.

\begin{tabular}{|c|c|c|c|c|c|}
\hline \multirow{2}{*}{$\begin{array}{c}\text { Sampel Fitoplankton } \\
\text { Laut }\end{array}$} & \multirow{2}{*}{$\begin{array}{l}\text { Ukuran } \\
(\mu \mathrm{m})\end{array}$} & \multirow{2}{*}{$\begin{array}{l}\text { Waktu } \\
\text { (hari) }\end{array}$} & \multicolumn{2}{|c|}{ Pengamatan (sel/mL) } & \multirow{2}{*}{$\begin{array}{c}\mu \\
\left(\mathrm{Jam}^{-1}\right)\end{array}$} \\
\hline & & & $\mathbf{N}_{0}$ & $\mathrm{~N}_{\mathrm{t}}$ & \\
\hline D. salina $(A 6)$ & $5-8$ & 9 & 100.000 & 22.430 .000 & 0,0251 \\
\hline D. salina (A9) & & 4 & 100.000 & 8.140 .000 & 0,0458 \\
\hline C. vulgaris(B7) & $3-4$ & 8 & 100.000 & 112.500 .000 & 0,0366 \\
\hline C. vulgaris (B4-1) & & 6 & 100.000 & 97.000 .000 & 0,0573 \\
\hline Spirulina sp. (16) & $5-7$ & 9 & 100.000 & 110.300 .000 & 0,0325 \\
\hline Spirulina sp. (14-1) & & 4 & 100.000 & 59.850 .000 & 0,0667 \\
\hline
\end{tabular}

Informasi ini memperlihatkan fungsi ion logam $\mathrm{Fe}$, Co dan $\mathrm{Ni}$, apabila diintegrasikan dengan pupuk urea dan pupuk ZA akan mampu memperbanyak sel fitoplankton laut, sekaligus mempertegas kemungkinan penemuan medium yang lebih ekonomis, jika dibandingkan dengan medium yang telah ada dan komposisi komponennya banyak serta harganya relatif lebih mahal. Kondisi ini jelas menjadi informasi penting, agar nantinya dapat terus dilakukan pengkajian secara lebih serius, terhadap pencarian berbagai alternatif jenis komponen nutrien 
yang dapat berfungsi menstimulasi laju pembentukan biomassa sel spesies fitoplankton laut yang lebih cepat pertumbuhannya dan lebih banyak akumulasi selnya.

\section{Kultur Massal Spesies Fitoplankton Laut Uji}

Hasil penentuan kandungan biomassa fitoplankton laut, disajikan pada Tabel 14.

Tabel 14. Kandungan

Biomassa Fitoplankton Laut.

\begin{tabular}{ccc}
\hline No. & $\begin{array}{c}\text { Spesies } \\
\text { Fitoplankton } \\
\text { Laut }\end{array}$ & $\begin{array}{c}\text { Berat Kering } \\
\text { Biomassa } \\
\text { Fitoplankton Laut } \\
(\mathbf{g} / \mathbf{L})\end{array}$ \\
\hline 1 & D. salina & $\mathbf{0 , 3 0 9 5}$ \\
2 & C. vulgaris & $\mathbf{0 , 3 7 8 2}$ \\
3 & Spirulina $s p$. & $\mathbf{0 , 3 3 2 5}$ \\
\hline
\end{tabular}

Berdasarkan data pada Tabel 14, diperoleh kandungan berat kering biomassa fitoplankton laut tertinggi adalah 0,3782 $\mathrm{g} / \mathrm{L}$ untuk spesies Chlorella vulgaris, dan kandungan biomassa fitoplankton laut terendah diperoleh dari spesies Dunaliella salina yaitu sekitar 0,3095 g/L, namun ketiga spesies fitoplankton laut memperlihatkan hasil yang relative sama, menunjukkan bahwa ketiganya berpotensi untuk dilakukan kultur massal.

\section{Hasil Analisis Karbohidrat}

Analisis kandungan karbohidrat dalam biomassa spesies fitoplankton laut dilakukan dengan menggunakan metode penentuan gula reduksi yaitu cara Luff Schoorl, hasilnya diperlihatkan pada Tabel 15.

Sesuai data pada Tabel 15, diperoleh akumulasi kandungan karbohidrat tertinggi dalam biomassa fitoplankton laut adalah dari spesies $D$. salina yaitu sekitar $32,49 \% \mathrm{~b} / \mathrm{b}$, dan akumulasi terendah pada spesies Spirulina $s p$. yaitu sekitar 29,81 \%b/b. Kondisi ini menunjukkan bahwa fitoplankton yang memiliki bentuk morfologi dan ukuran sel yang lebih besar seperti Dunaliella salina memiliki potensi membentuk karbohidrat lebih banyak, informasi ini sesuai dengan yang disampaikan oleh Guerrero (2010).

Tabel 15. Data Kandungan dan Kadar Karbohidrat Fitoplankton Laut Hasil Kultur untuk volume $1000 \mathrm{~mL}$.

\begin{tabular}{llccc}
\hline No & Jenis Fitoplankton & $\begin{array}{c}\text { Berat Kering } \\
\mathbf{( m g )}\end{array}$ & $\begin{array}{c}\text { Berat } \\
\text { Karbohidrat } \\
(\mathbf{m g})\end{array}$ & $\begin{array}{c}\text { Kadar } \\
\text { Karbohidrat } \\
(\mathbf{\%} \mathbf{b} / \mathbf{b})\end{array}$ \\
\hline 1 & D. salina & 0,3095 & 0,1006 & 32,49 \\
2 & C. vulgaris & 0,3782 & 0,1195 & 31,58 \\
3 & Spirulina sp. & 0,3325 & 0,0991 & 29,81 \\
\hline
\end{tabular}

\section{Hasil Analisis Lemak}

Hasil kandungan lemak dalam spesies fitoplankton laut uji yang dianalisis menggunakan metode soxhlet (SNI 245390) dengan pelarut n-heksanaadalah, diperlihatkan pada Tabel 16. 
Berdasarkan Tabel 16, diperoleh kandungan lemak tertinggi pada fitoplankton laut spesies Chlorella vulgaris yaitu 26,82 \%b/b,dan kandungan lemak terendah pada fitoplankton laut spesies Spirulina sp. yaitu sekitar $24,53 \% \mathrm{~b} / \mathrm{b}$.

Hasil yang diperoleh menunjukkan bahwakompleksitas sistim morfologi dan proses metabolisme pada fitoplanktondapat berpengaruh terhadap akumulasi senyawa organik hasil metabolisme yang lebih besar dalam jaringan morfologi fitoplankton tersebut, khususnya senyawa organik penyusun molekul lemak seperti gliserol, asam karboksilat, trigliserida dan lain-lain (Parker, 1998; Ragauskaset al., 2006).

Tabel 16.Kandungan dan Kadar Lemak Fitoplankton Laut Hasil Kultur massal.

\begin{tabular}{clccc}
\hline No. & Jenis Fitoplankton & $\begin{array}{c}\text { Berat Kering } \\
(\mathbf{m g})\end{array}$ & $\begin{array}{c}\text { Berat Lemak } \\
(\mathbf{m g})\end{array}$ & $\begin{array}{c}\text { Kadar Lemak } \\
(\mathbf{\%} \mathbf{b} / \mathbf{b})\end{array}$ \\
\hline 1 & D. salina & 0,3095 & 0,0803 & 25,95 \\
2 & C. vulgaris & 0,3782 & 0,1015 & 26,82 \\
3 & Spirulina sp. & 0,3325 & 0,0816 & 24,53 \\
\hline
\end{tabular}

Informasi ini menunjukkan potensi kultur massal ketiga spesies fitoplankton laut yaitu Dunaliella salina, Chlorella vulgaris dan Spirulina sp., sehingga dapat dilakukan kultur lebih lanjut dalam skala lebih besar atau kultur biomassal menggunakan nutrien MSSIP yang ditemukan untuk mendukung kesiapan dan ketersediaan bahan baku produksi biofuel jenis bioetanol dan biodisel.

\section{KESIMPULAN}

1. Jenis fitoplanton laut yang dianalisis dengan nutrien MSSIP adalah: Dunaliella salina, Chlorella vulgaris dan Spirulina $s p$.

2. Nutrien MSSIP yang digunakan, memiliki kemampuan yang baik untuk menumbuhkan fitoplankton laut pada skala kultur murni germinasi dan kultur massal, sebagaimana nutrien yang lain yang telah dilakukan pada penelitian terdahulu mulai dari Nutrien Conway, Arschat, Arschat-M dan Syabr-1.

3. Ion logam $\mathrm{Fe}$, Co dan Ni merupakan logam yang dibutuhkan oleh fitoplankton laut dalam pertumbuhannya selama digunakan dengan jumlah perbandingan yang tepat.

4. Kandungan biomassa ke tiga fitoplankton laut yang dianalisis, potensil untuk dijadikan sebagai bahan bakuuntuk produksi biofuel jenis bioetanol dan biodiesel apabila diproduksi pada kultur secara kontinyu, oleh karena kandungan biomassa, karbohidrat dan lemaknya yang cukup tinggi.

\section{DAFTAR PUSTAKA}

Arifin. 2010. Bioakumulasi Ion Logam Cd Oleh Fitoplankton Laut Tetraselmis Chuii dan Chaetoceros Calcitrans. Desertasi tak diterbitkan. Makassar: 
Program Studi Kimia Pasca Sarjana Unhas.

Bu-Olayan AH., Al-Hassan R., Thomas BV., Subrahmanyam MNV. 2011. Inpact of Trace Metals and Nutriens Levels on Phytoplankton from the Kuwait Coast. Environment International. 26(4):199-203.

Cermeno P., de Vargas C., Abrantes F., Flakowski PG. 2010. Phytoplankton Biogeography and Community Stability in the Ocean. Plosone. 5(4): e10037.

Chisti Y. 2008. Biodiesel from microalgae beats bioethanol. Trend in Biotechnology. 26(3): p 126-131.

Coleman R. D., R. L. Coleman, E. L. Rice. 2008. Zinc and Cobalt Bioconcentration and Toxicity in Selected Algae Species. Botanical Gazette. 139(2): 102-109.

Cotton, F. Albert, 1989. Kimia Anorganik Dasar. Jakarta: Universitas Indonesia Press. 144-186.

Goksan, T. Zekeriyaoglu, A. AK, Ilknur. 2007. The Growth of Spirulina platensis in Different Culture Systems Under Greenhouse Condition. Turkish Journal of Biology. 31(1): 47 - 52.

Guerrero M.G. 2010. Bioethanol from Microalgae. Sevilla: Instituto Bioquiimica Vegetaly Fotosmica Fotosiintesisntesi. pp 26.

Hadiyanto, Istiyanto Samidjan, Andri Cahyo Kumoro dan Silviana. 2010. Produksi Mikroalga Berbiomassa Tinggi dalam Bioreaktor Pengembangan Teknologi Kimia untuk Pengolahan Sumber Daya Alam Indonesia. Prosiding Seminar Nasional Teknik Kimia "Kejuangan"; Yogyakarta, 26 Januari 2010. Yogyakarta: UPN Veteran Yogyakarta. HIm 104-112.

Hedges JI., Geinas Y., Baldock JA., Wakeham S. 2002. The biochemical and Elemental Compositions of Marine Plankton (A NMR Perspective). Marine Chemistry. 78(1): 47-63.
Kasim S., M. Sjahrul. 2012. Isolation and Identification of Marine Phytoplankton for Production of Carbohydrate Type Biomass. Journal European Chemical Bulletin (ECB). 1(8): 311-316.

Kasim S., M. Sjahrul. 2012. Pemanfaatan Fitoplankton Laut untuk Produksi Bahan Bakar Nabati Berbentuk Bioetanol. Makassar: Jurusan Biologi Fakultas MIPA Unhas.

Kasim, S., 2016. The Study of Marine Phytoplankton Species as The Producer of Biomass and Biofuel Grown in Culture With The Integrated Nutrient of Metal lons Fe, Co and Ni. [Disertasi S3]. Makassar: Pasca Sarjana Jurusan Kimia Fakultas Mipa Unhas.

Khan S.A., Rashmi, Hussain Mir, Z., Prasad, S., Banerjee, U.C., 2009. Prospects of Biodiesel Production from Microalgae in India. Journal of Renew Sust Energy Rev. 13:236172.

Morel, Francois M.M., 2008. The CoEvolution of Phytoplankton and Trace Element Cycles in the Oceans. J. Compil. Geobiol. 6: 318324.

Wu N., Fohrer N., Scmalz B. 2010. Distribution of Phytoplankton in a Germand Lowland Driver in Relation to Environmental Factor. Journal Plankton Res. 33: 807-820.

Nontji. A. 2008. Plankton Laut. Jakarta: LIPI Press.

Parker D. L. 1998. Effects of Cellular Metabolism and Viability on Metal Ion Accumulation by Cultured Biomass from a Bloom of the Cyanobacterium microcystis aeruginosa. J. ASM.org. App. and Environ.Microbiol. 64(4):1545.

Ragauskas A.J., Williams, C.K., Davison, B.H., Britovsek, G., Cairney, J., Eckert, C.A., Frederick, W.J., Hallett, J.P., Leak, D.J., Liotta, C.L., Mielenz, J.R.Murphy, R., Templer, 
R., Tschaplinski, T. 2006. The Path Forward for biofuels and biomaterials. Science 311: 484-489.

Rodolfi I., Zittelli, G.C., Bassi, N., Padovani, G., Biondi, N., Bonini, G. et al. 2008. Microalgae for Oil: Strain Selection, Synthesis and Outdoor Mass Cultivation in a Low-Cost Photobioreactor. Biotechnologi Bioeng. 102(1):100-12.

Sanchez. M., Castillo, J.B., Rozo, C. Rodriguez, I. 2008. Spirulina (Arthrospira): $\quad$ An-Edible Microorganism. A Review. Javeriana Cra. Bogota. 7: 43-88.

Sanusi, H. S. 2006. Kimia Laut. Proses Fisik Kimia dan Interaksinya dengan Lingkungan. Bogor: IPB.

Sharma K., Schuhmann H., Schenk PM. 2012. High Lipid Induction in Microalgae for Biodiesel Production. Energies. 5(5): 1532-1553.

Sjahrul, M., 2010. Dasar-Dasar Kimia Anorganik. Makassar: PT. Umitoha Ukhuwah Grafika.

Sugiyarto, Kristian H., 2012. Dasar-Dasar Kimia Anorganik Transisi. Yogyakarta; Graha ilmu. pp 116175. 